\title{
THE EFFECTIVENESS OF CLT METHOD IN IMPROVING ENGLISH STUDENTS ABILITY IN KSK INSTITUTE OF FATHIMATUZZAHRO
}

\author{
BRADHIANSYAH TRI SURYANTO \\ Universitas Nurul Jadid Paiton Probolinggo \\ bradhiansyahs@gmail.com \\ ULFATUL NIKMATILLAH \\ Universitas Nurul Jadid Paiton Probolinggo \\ ulfatulnikmatillah1@gmail.com
}

\begin{abstract}
The aims of this study are to: 1) Investigate the English learning process by using the CLT method in KSK Institute of Fathimatuzzahro, Nurul Jadid Islamic Boarding School, 2) Investigate the effectiveness of the CLT method in improving students' English ability, 3) Investigate the perception of students of KSK Institute of Fathimatuzzahro, Nurul Jadid Islamic Boarding School on English language skills after participating in learning process by using the CLT method, 4) Investigate the supporting and inhibiting factors in increasing the effectiveness of the English learning process in KSK Institute of Fathimatuzzahro, Nurul Jadid Islamic Boarding School. Theories and concepts used include: CLT learning methods, and English communication skills. The method used in this research is descriptive method with a quantitative approach. Data collection techniques used in this research, namely questionnaire, interview, observation and test. The sample of this research is 70 students of KSK Institute of Fathimatuzzahro, Nurul Jadid Islamic Boarding School. Based on the results of data processing, it was obtained that the CLT Learning Method gave significant effect on the English communication skills. In general, the average value of the CLT learning method variable scores implemented in the learning process in KSK Institute of Fathimatuzzahro, Nurul Jadid Islamic Boarding School in upgrading English communication skills have high qualifications, score per aspect of students perceptions in KSK Institute of Fathimatuzzahro, Nurul Jadid Islamic Boarding School on students' English proficiency using the CLT learning method is in the high category and score of each aspects of supporting and inhibiting factors in increasing the effectiveness of the learning process English courses in KSK Institute of Fathimatuzzahro, Nurul Jadid Islamic Boarding School are in the high category.
\end{abstract}

Keywords: CLT Method, Improving, English Students Ability

\section{INTRODUCTION}

The improvement of English skills of Indonesian people is still relatively low. The results of studies conducted by EF, the English Proficiency Index in Indonesia in 2019 is ranked 61 out of 100 countries with a proficiency index score of 50.06 (Index, 2019). Indonesian Language Proficiency Index value according to the data has decreased, considering that in 2018, Indonesia is ranked 51 with an English Proficiency Index value of 51.58 (EF, 2018).

While today, English communication skills are needed, especially in the world of education and the world of work. Many companies recruit workers by requiring them to be able to talk English. Perhaps English can be found in formal education, but in the implementation, formal education did not teach English speaking adequately, so students often experienced confusion and difficulty in communicating using English. Based on the results of research in several decades, English language skills include listening skills, speaking, reading and writing. This was revealed by H.D. Brown that for more than six decades now, research and practice in English language teaching has identified the four skills - listening, speaking, reading, and writing - as of paramount importance (Brown, 2007). Therefore, educational services are needed for the community regarding learning English. Educational services that provide English language learning can be obtained both inside and outside of school. One of the educational services for learning English in schools can be provided at extracurricular activities.

In Article 26 paragraph 4 of Law No. 20 of 2003 concerning the National Education System (Indonesia, 2003), the course institution is a non-formal education unit. In article 26 paragraph 5 it is explained that courses and training are held for people who need the knowledge, skills, life skills and attitudes to develop themselves, develop the profession, work, independent business and / or continue their education to a higher level. Also completed with article 103 paragraph 1 PP No. 17 of 2010 concerning the management and organization of education that courses and training are held for the community in order to develop professional personality and to improve vocational competencies of course learners (Indonesia, 2010).

Course institution is an institution that organizes course activities, either by individuals or groups / institutions and obtains permission from the competent authority, courses can also be 
held by international institutions or foreign private institutional bodies in the territory of the Republic of Indonesia provided that they are subject to the laws and regulations prevailing in Indonesia (Artasasmita, 1985). In learning English requires a method for learning more effective and also efficient. Likewise, learning English in the KSK Institute - a Special Study Group which is located in the Fathimatuzzahro dormitory of Nurul Jadid Islamic Boarding School. The learning method used in teaching participants to understand English, namely using the Communicative Language Teaching (CLT) method. This method has been used in KSK Institute of Fathimatuzzahro for 20 years. KSK Institute has graduated hundreds of people, not a few participants who have gone abroad to earn a living or to settle there. The general objective of this research is to assess the effectiveness of the Communicative Language Teaching (CLT) Method in Improving the Communication Skills of English Language Learning Participants in KSK Institute of Fathimatuzzahro. The specific objectives of the study are to: Know the process of learning English with CLT learning methods for students in KSK Institute of Fathimatuzzahro. Knowing the effectiveness of CLT learning methods in improving the English skills of participants in KSK Institute of Fathimatuzzahro. Knowing the participants' perceptions of KSK Institute of Fathimatuzzahro of English language skills after participating in learning using the CLT method. Knowing the supporting and inhibiting factors in increasing the effectiveness of the learning process of English courses in KSK Institute of Fathimatuzzahro.

In learning English a method is needed so that learning is more effective and also efficient. Likewise, learning English through English Time program which is carried out as an extracurricular activity in Tarbiatut Mubtadiat Dormitory, Nurul Jadid Islamic Boarding School. In the English Time program the learning method used to teach English to participants so that they can understand English quickly and easily is the Communicative Language Teaching (CLT) method.

The objectives of this study are as follows:

1. Knowing the process of learning English with CLT learning methods for participants in the English Time program.

2. Knowing the effectiveness of CLT learning methods in increasing the participant's English skills in the English Time program,

3. Knowing the perception of the participants of the English Time program towards English language skills after participating in learning procress by using the CLT method.

4. Knowing the supporting and inhibiting factors in increasing the effectiveness of the learning English process in the English Time program.

\section{Review of literature}

The concept of out-of-school education is reviewed by expert fees. Coombs, in Sudjana stated that education outside school is any educational activity that is organized, carried out separately or is an important part of a broader activity with the aim of providing special services to learning citizens in achieving learning goals (Sudjana, 2006). According to Mambili stated that nonformal education can be operationally defined as an organised, structured and systematic learning service delivered outside the framework of formal school system to a specific group(s) of people for a specific objective, at low cost in terms of both time and resources (Mambili, 2004). Meanwhile, in the Law of the Republic of Indonesia Number 20-year 2003 Article 1 paragraph 1 concerning the National Education System, out-of-school education is known as non-formal education, which is the path of education outside of formal education that can be implemented in stages. Non-formal education is held for citizens who need education services that function as substitutes, additions, and / or complementary formal education in order to support lifelong education. Meanwhile, in Article 26 Paragraph 4 stated that non-formal education units consist of course institutions, training institutions, study groups, community learning centres, and assemblies, and similar educational units (Indonesia, 2003).

The course is derived from English, which is a course that literally means a subject or series of lessons (Wjs, 2006). Meanwhile, according to Artasasmita (Artasasmita, 1985) the course is as a course of learning activities that take place in the community carried out deliberately, organized, and systematically to provide certain subject matter to adults or adolescents in a relatively short time so that they gain knowledge, skills, and attitudes which can be utilized to develop from and society. Examples: sewing courses, computer courses, and beauty courses. 
The course is a training institution that is included in the type of non-formal education. The course is a teaching-learning activity just like a school. The difference is that the course is usually held in a short time and only to learn one skill. For example, a three-month English course, a mechanic's course, a cooking course, a sewing course, and a music course. Participants who have taken the course well can obtain a certificate or certificate. For certain skills, such as beauty courses or hairdressers, course participants are required to take a state exam. The State Examination is intended to oversee the quality of the courses concerned, so that the lessons given meet the requirements and participants have skills in their fields. Conceptually, the course is defined as a process of learning about knowledge or skills that are held in a short time by an institution oriented towards the needs of the community and the business / industrial world. Whereas Non-formal Education Institutions are educational institutions that provide non-formal education for the community, both initiated by the government and the community. Development of an activity carried out effectively, efficiently, continuously to obtain more results. So that Course and Institutional Development is a formation of PNF courses and institutions through the PNF learning and institutional management process so that it is able to produce quality, competent and competitive graduates in the global market arena.

Traditionally, the method is interpreted to convey learning material. In its development, the method is meant more than just conveying learning material, but includes the ways taken by a teacher, facilitator, tutor, or instructor to facilitate students or students' learning objectives. This includes procedures or steps for the activities carried out by the teacher / instructor or students / student targets to achieve learning objectives. These learning activities can include flexible spatial planning, seating, grouping of learning citizens, activities on educational radio broadcasts, activities in writing in magazines and newspapers, field trips, interviews with community leaders, observations to certain places or events and so on. Usually large-scale activities are called methods, the small ones are called techniques and sometimes people just equate the two as methods.

Learning methods of Communicative Language Teaching (CLT) or commonly referred to as communicative learning methods. This method includes several language skills, namely reading, listening, conversation and grammar (Richards, 2005). Thus the aim of teaching language is to develop what is called for by Hymes as a communicative competence, namely the ability to use language for various purposes and in various situations and conditions (Hymes, 1972). Thus, the use of language is not only limited to four language skills, but includes several abilities within a broad communication framework, according to the role and participants of the situation, and the purpose of interaction. Furthermore, hopefully the communicative language teaching method was highly effective to achieve the goals of teaching English, such as teaching students to acquire vocabularies, grammatical understanding, and good pronunciation (Suryanto, 2019).

According to Ihat Hatimah (Hatimah, 2000), the position of the method in learning has scope for; 1) provide encouragement, which is a way to use learning resources to provide encouragement to learning participants to continue to want to learn, 2) bring up and increase interest in learning, which is a way to foster stimulation for the growth of students' learning interest based on their needs, 3) deliver learning material, namely how to use learning resources in conveying material in learning activities, 4) creating a conducive learning climate, which is a way to create a pleasant learning atmosphere for participants to learn to learn, 5) triggering energy to present the learning participants creativity in accordance with their potential, 6 ) encourages self-assessment in the process and learning outcomes, i.e. how to find out the success of learning, and 7) encourages to overcome the weaknesses of learning outcomes, i.e. how to find solutions to problems encountered in learning activities.

The purpose of teaching language with communicative methods is to develop student competencies in communicating by developing student competencies in communicating with target languages in real communicative contexts or in real life situations (social context) (Fachrurrozi \& Mahyuddin, 2010). Communicative abilities require the ability to use language that suits a particular social context. To be able to have such abilities, students need knowledge of the forms, meanings and functions of language. They need to know that many forms of language can be used for one function, and also that a form of language can often be used for various functions. They must be able to choose from many forms of language, which are the most appropriate to use, understand the social context and the roles of the people involved in 
communication. They must also be able to manage the process of negotiating meaning with their interlocutors.

Communication emphasizes more on the social aspect, namely efforts to make things belong together or known together or with other statements, that seen from the origin of the word in the sense that initially communication focused more on social activities and processes (Susanto, 1974). Communication is everywhere, in homes, campuses, offices, and mosques; even he is able to touch all aspects of our lives (Rakhmat, 2001). This means that almost all human activities, wherever they are, are always touched by communication. In the field of fabric such as management, administration, law, mathematics and biology, for example, communication has always been an inseparable part of the development process Administration cannot live without communication. The education sector, for example, cannot work through communication. In other words, there is no educational behaviour that is not born by communication.

Education communication in question is communication that has penetrated or touched the world of education with all its aspects. The target or communicant is a group of people, usually homogeneous, although sometimes also a bit heterogeneous, both formal and informal groups. Students, students, training participants, upgrading participants, seminar participants, farmer group members in the village, group members in a community that is spread out in the community, members of social organizations, employees, private employees, are examples that are included in the target or communicant. The general function of communication is informative, educative, persuasive, and recreational (entertainment). The point in brief is that communication functions to provide information provide data or facts that are useful for all aspects of human life. Besides that, communication also functions to educate the community, educate everyone towards achieving maturity and independence. Persuasive function means that communication is able to persuade people to behave in accordance with the desires of the communicator or initiator of communication. While the latter is an entertainment function, which can entertain people when possible, for example listening to fairy tales, doing extensive reading, and watching television shows.

In the implementation of formal education (education through schools), it is clear that there is a very prominent communication role. The teaching and learning process is mostly due to the communication process, both intrapersonal and interpersonal. Intrapersonal appear in the event of thinking, perceiving, remembering, and sensing. This is experienced by every member of the school, even by everyone. While interpersonal is a form of communication that proceeds from the existence of ideas and information from one person to another person. Communication here is mainly what happens in instructional activities such as teaching and learning in face-to-face activities or other instructional (Yusuf, 2010).

According to Richard and Roger language is a tool for communication (Richards, 2005). Thus the use of language is not only limited to four language skills, but includes several abilities within a broad communication framework, according to the role of the participant, the situation, and the purpose of the interaction.

The ability of English, especially in communication, has become something very important for the public to master to face the era of globalization that has been going on in recent years. The efforts of each individual to develop this ability can also be reflected in our own community who are already quite active in using English in the world of work and education. English according to $\mathrm{H}$. Brown basically consists of several kinds of abilities, namely reading, listening, speaking, writing and conversation skills (Brown, 2000). We receive and learn the four skills in schools and other English language training institutions. The improvement of the participants' English communication skills can be seen from their fluency in speaking English, the grammar used, vocabulary mastered, and expressions used in speaking English.

\section{METHOD}

The research method is generally understood as a scientific activity that is carried out in stages starting with the determination of topics, collecting data and analyzing data, so that later an understanding and understanding of certain topics, symptoms or issues will be obtained. It is said to be 'gradual' because this activity takes place following a certain process, so there are steps that need to be passed in stages before moving on to the next stage.

The research method used is experimental method with a quantitative approach. The purpose of using descriptive methods is to solve the problem or answer the problem being faced. While the purpose of using a quantitative approach is to find out the magnitude of the effectiveness of 
the CLT learning method in improving the participants' English communication skills. The first stage is data collection, the second is compiled, the third is explained, and the fourth is analyzed so that researchers can draw conclusions by distributing questionnaires or questionnaires and how to process them through percentage calculations. The stages are carried out by collecting, classifying and processing data, making conclusions and reports with the main aim of making a description of a situation objectively in a situation. By using descriptive methods, the writer can describe the results of the research with existing problems by focusing on the conditions which is factual in accordance with when the research was carried out. The data collection techniques carried out in this study from the instruments as follows:

1. Observation

In this stage the researcher made observations on the process of teaching and learning English in KSK Institute of Fathimatuzzahro. Then based on data and information obtained from observations researchers tried to understand them based on knowledge and methods of communicative language teaching, to obtain the information needed to continue the study.

2. Interview

In this stage the researchers conducted interviews with students KSK Institute of Fathimatuzzahro directly. The purpose of the interview was to get precise and accurate information from the students about the use of communicative language teaching methods during the process of teaching and learning English in KSK Institute of Fathimatuzzahro. Besides giving questions, in the interview the researcher also provides advice about communicative language methods teaching to students.

3. Questionnaire

Questionnaire was given to the students in order to obtain data efficiently and precisely about the variables to be measured. In addition, the questionnaire was also intended to find out the opinions, attitudes, and expectations of students towards the use of communicative language teaching methods in the teaching and learning process of English in KSK Institute of Fathimatuzzahro.

4. Test

There were two tests given. The tests were speaking tests. The first speaking test was pre-test. The test was given to assess the level of knowledge or skills in terms of English speaking. And the second speaking test was post-test. The test was given to assess the result of the treatments. The instruments assigned to the students are provided by the researcher in a similar way (Suryanto, 2018).

\section{FINDINGS AND DISCUSSION}

\section{CLT learning methods in KSK Institute of Fathimatuzzahro}

To see how the CLT method in KSK Institute of Fathimatuzzahro was applied as one of the most effective learning methods, it can be noted from various aspects that influence the learning objectives, learning materials, human resources, time and supporting facilities.

In terms of learning objectives of each lesson taught to students who are very communicative and very capable of students to better understand, besides learning materials that had been provided for learning by students deliberately compiled by all administrators on duty, delivered in the book has been based on the analysis of the extracts of a number of other special English so that the material in the book really can already be easily understood.

\section{Ability to master the English language in KSK Institute of Fathimatuzzahro}

Based on the analysis of the data obtained by researchers from the distribution of questionnaires and the provision of tests to 11 students in KSK Institute of Fathimatuzzahro, it can be concluded that the ability of the students in mastering English language proficiency is categorized high, namely between $70-85$, precisely $90 \%$ students scored at $72-85$. This showed that the students in KSK Institute of Fathimatuzzahro have good scores in English. So that it can be said that the English course namely, KSK Institute of Fathimatuzzahro is able to fulfil all aspects that can improve the English language skills of students.

The total score of this variable in English communication ability is obtained from the results of the test scores at the KSK Institute of Fathimatuzzahro which consists of 4 aspects taken to measure English communication skills at the KSK Institute of Fathimatuzzahro. These four aspects were listening and writing. In general, regarding the ability to read, participants have a pretty good value, the maximum reading score of 11 participants is 80 , the minimum reading 
score of 11 participants is 70 , the median reading score of 11 participants is 75 and the average reading score of 11 participants is 75.34 . In general, regarding speaking ability, students have good grades, the maximum speaking score of 11 participants is 80 , the minimum speaking score of 11 participants is 70, the median speaking score of 11 participants is 78 . In general, regarding listening ability, participants have good value, the maximum value of listening scores of 11 participants was 85 , the minimum value of listening scores of 11 participants was 70 , the median listening score of 11 participants was 80 . In general, regarding writing ability, participants had good grades, the maximum value of writing scores of 11 participants were 80 , the minimum writing score of 11 participants was 65 , the median writing score of 11 participants was 75 .

\section{Effectiveness of CLT Learning Methods in Improving English Language Communication}

The effectiveness of a CLT method can be seen from the extent of success in terms of the achievement of the targets that have been set, for example are students with indicators of the number of learning citizens who take an English course divided into several levels, namely 3 levels with the division of several levels the coaching is more effective also in terms of time and energy to be more efficient. Based on the results of research that has been done, it was concluded that the CLT learning method has a strong relationship with English communication skills. This conclusion is based on the interpretation in the Guildford table which states that the correlation coefficient value of CLT learning methods to English communication skills of 0.762 is at the interval of a strong relationship level. Then the results of the hypothesis $t$ test which states that there is an influence between CLT learning methods and communication skills in English have been accepted because it has a calculated value greater than $t$ table $(8.141>2.011)$ and the probability of error is still below the alpha level set $(0,000<0,05)$. The magnitude of the calculated reading ability of 2,377 is greater than the table of 2,011 and the probability of error is still below the alpha level specified $(0.022<0.05)$. determined $(0.004<0.05)$. The amount of listening ability counted 5,141 is greater than the table of 2,011 and the probability of error is still below the established alpha level $(0,000<0.05)$. A positive correlation value indicates that the more effective CLT learning method, it is predicted that the communication skills of English speaking KSK Institute course participants will tend to increase. Then based on the results of the calculation of the R-Square or the coefficient of determination of reading of 0.105 , it means that the reading ability of the students of KSK Institute of Fathimatuzzahro is influenced by the CLT reading learning method by $10.5 \%$. Based on the calculation of the R-Square or the coefficient of determination of speaking of 0.158 , it means that the speaking ability of the students of KSK Institute of Fathimatuzzahro is influenced by the learning method.

Based on the results of the calculation of the R-Square or listening determination coefficient of 0.317 means that the conversation skills of the students of KSK Institute of Fathimatuzzahro is influenced by the CLT writing learning method by $31.7 \%$. Based on the results of simple linear regression calculations obtained by the reading equation $\mathrm{Y}=23,435+$ $0.787 \mathrm{X}$, this means that the reading ability is worth 23,435 if there is no reading method. But if there is a reading method then reading ability increases by 0.787 . Speaking equation is $Y=$, this means speaking ability is valuable if there is no speaking method. But if there is a grammar method, the ability of grammar increases by 0.211 . The listening equation is $Y=2,151+1,083 \mathrm{X}$, this means that conversation skills are worth 2,151 if there is no listening method. But if there is a listening method the listening ability increases by 1,083 . Then based on the results of the calculation of the R-Square or the coefficient of determination of 0.580 means that the English language communication skills of the students of KSK Institute of Fathimatuzzahro is influenced by the CLT learning method by $58 \%$. Then the rest $(100 \%-58 \%=42 \%)$ is influenced by other factors not examined by the author.

\section{The Perceptions of the students of KSK Institute of Fathimatuzzahro toward English Language Ability Using the CLT Method}

In general, the score per aspect of perceptions of course participants at the KSK Institute on participants' English communication skills using CLT learning methods is in the high category. This can be seen from the results of data processing where $80.7 \%$ of respondents gave an opinion that CLT learning methods can increase English knowledge. $74.8 \%$ of respondents gave an opinion that CLT learning methods can improve the practice of speaking English. $75.9 \%$ of respondents gave the opinion that CLT learning method can improve English experience. 
$74.8 \%$ of respondents gave an opinion that CLT learning methods can increase interest in speaking English. The average score of perception aspect score is $76 \%$ which means that the perception of respondents / participants stated that after participating in learning using the CLT method, the English language skills of the students of KSK Institute of Fathimatuzzahro improved, especially in communication. Based on the perception of respondents / students the number of scores that answered the reading indicators were 3049, the speaking indicator 2971, and the listening indicator 3690. From the results of the score it showed that most participants preferred the listening method in improving their English communication skills and the second reading and the third speaking.

\section{Supporting and inhibiting factors in increasing the effectiveness of the learning process of English courses in the KSK Institute of Fathimatuzzahro}

In general the score scores per aspect of supporting factors in increasing the effectiveness of the learning process of English courses in the KSK Institute of Fathimatuzzahro are in the high category. This can be seen from the results of data processing in which $74.4 \%$ of respondents gave an opinion that teaching factors, teaching materials and learning methods largely determine participants in mastering reading, speaking, listening and writing in English. $73.3 \%$ of respondents who gave the opinion that the tutor explained the material clearly and easily understood tutors provided input and knowledge about communication in English properly and correctly. $74.4 \%$ of respondents gave the opinion that reading, grammar, and conversation learning facilities in English really determine the participants in mastering in English. In general the score scores per aspect of the inhibiting factors in increasing the effectiveness of the learning process of English courses in the KSK Institute of Fathimatuzzahro are in the high category. $79.2 \%$ of respondents gave the opinion that the tutor gave too many assignments to the participants so that sometimes the participants felt dizzy and in their learning the tutors often used English so that sometimes the participants felt confused.

\section{CONCLUSION}

In general, the average score of CLT learning method variables carried out in the learning process in the KSK Institute of Fathimatuzzahro in improving English communication skills has high qualifications. CLT learning methods implemented in the learning process in the KSK Institute of Fathimatuzzahro which have an influence in improving the communication skills of participants in English range in the sufficient category. In general, the score per aspect of perceptions of course participants in the KSK Institute of Fathimatuzzahro on students' English proficiency using CLT learning methods is in the high category. The average score of perception aspect score is $76 \%$ which means that the perception of respondents / participants stated that after participating in learning using the CLT method, the English language skills of the students of KSK Institute of Fathimatuzzahro improved, especially in communication. In general, the score scores per aspect of supporting and inhibiting factors in increasing the effectiveness of the learning process of English courses in the KSK Institute of Fathimatuzzahro are in the high category.

\section{REFERENCES}

Artasasmita, R. (1985). Pedoman Merancang Sistem Kursus dan Latihan. Bandung: Jurusan Pendidikan Luar Sekolah IKIP Bandung.

Brown, H. D. (2000). Principles of language learning and teaching.

Brown, H. D. (2007). Principles of language learning and teaching fifth edition. White Plains, NY: Pearson Education.

EF, E. P. (2018). EF English Proficiency Index. Obtenido de EF English Proficiency Index: https://www. ef. com. ec/epi ....

Fachrurrozi, A., \& Mahyuddin, E. (2010). Pembelajaran Bahasa Asing: Metode Tradisional dan 


\section{VOL. 02 NO. 01, JUNE 2020}

Kontemporer. Jakarta: Bania Publishing.

Hatimah, I. (2000). Strategi dan Metode Pembelajaran. Bandung: Adira.

Hymes, D. (1972). On communicative competence. Sociolinguistics, 269293, 269-293.

Index, E. F. E. P. (2019). A Ranking of 100 Countries and Regions by English Skills.

Indonesia. (2010). Peraturan pemerintah nomor 17 tahun 2010 tentang pengelolaan dan penyelenggaraan pendidikan. Pustaka Timur.

Indonesia, P. R. (2003). Undang-undang Republik Indonesia nomor 20 tahun 2003 tentang sistem pendidikan nasional. Jakarta: Pemerintah Republik Indonesia.

Mambili, E. (2004). The Position of Non-Formal Education in Kakamega District in the Face of Declared Free Primary Education, Accessing Quality Basic Education Trough Non-Formal Education. LIFA Programme Coordinator.

Rakhmat, J. (2001). Ilmu Komunikasi. Bandung: Rosda Karya.

Richards, J. C. (2005). Communicative language teaching today. SEAMEO Regional Language Centre Singapore.

Sudjana, D. (2006). Evaluasi Program Pendidikan Luar Sekolah: Untuk Pendidikan Nonformal dan Pengembangan Sumber Daya Manusia. Bandung: Remaja Rosdakarya.

Suryanto, B. T. (2018). WRITTEN GRAMMAR FEEDBACK ON STUDENTS'WRITING WITH VISUAL LEARNING STYLE. PEDAGOGIK: JURNAL PENDIDIKAN, 5(1), 1-18.

Suryanto, B. T. (2019). How to Teach Listening in Senior High School. IJOEEL: International Journal of English Education and Linguistics, 1(1), 42-48.

Susanto, P. A. S. S. (1974). Komunikasi dalam teori dan praktek (Vol. 1). Binacipta.

Wjs, P. (2006). Kamus Besar Bahasa Indonesia. Jakarta: Balai Pustaka.

Yusuf, P. M. (2010). Komunikasi Instruksional. Jakarta: Bumi Aksara. 